- розвиток уміння імпровізації прослуханого тексту.

Тип проекту: рольовий, практико-орієнтований, творчий.

Характер проекту: міжпредметний.

Розділи науки: країнознавство, англійська мова, інформатика.

Обладнання: комп'ютер, проектор, реквізити до імпровізації, слайди, тексти, ілюстрації, картки для оцінювання, папір, олівці, фломастери.

Очікуваний результат: імпровізація англійських традицій та свят. Створення альбому з короткою інформацією про ці свята.

Час роботи: 1 пара.

За кількістю учасників: груповий, парний.

Важливим моментом у проектній діяльності $є$ рефлексія, тобто аргументована оцінка власної діяльності й діяльності своїх партнерів, що закріплює уміння аналізу своїх і чужих дій та їх наслідків, успіху чи неуспіху, їх причини, прогнозувати висновки щодо майбутніх дій.

Використання методу проектів дає змогу студентам проявити творчість i активність, нестандартно мислити та діяти, приймати рішення і відповідати за свої дії окрім того, така робота позитивно впливає та розвиває змістовий, організаторський, психологічний, креативно-процесуальний, комунікативно-рефлексивний та аналітикооцінювальний компоненти, які $\epsilon$ показниками функціональної компетентності майбутніх учителів іноземної мови.

\title{
Література
}

1. Белякова М. А. Международная проектная деятельность как способ раскрытия творческого потенциала личности ученика / М. А. Белякова // Иностранные языки в школе. - 2007. - № 3. - С. 79-82. 3. Голуб Г. Б. Метод проектов как технология формирования ключевых компетентностей учащихся/ Г. Б. Голуб, О. В. Чуракова. - Самара, 2003. - 315 с. 3. Родигіна І. В. Компетентісно орієнтований підхід до навчання / Ірина Володимирівна Родигіна. - Х. : Основа, 2006. - 96 с.

Тетяна Стас

\section{ПЕДАГОГГЧНІ УМОВИ ФОРМУВАННЯ ЕМОЦІЙНОЇ КУЛЬТУРИ МАЙБУТНІХ УЧИТЕЛІВ ПОЧАТКОВОЇ ШКОЛИ ЗАСОБАМИ ОБРАЗОТВОРЧОГО МИСТЕЦТВА}

Стас Т. В. Педагогічні умови формування емоційної культури майбутніх учителів початкової школи засобами образотворчого мистецтва.

У статті схарактеризовано педагогічні умови формування емоційної культури майбутніх учителів початкової школи засобами образотворчого мистецтва: забезпечення емоційно-вольової регуляції змісту навчальної діяльності; застосування творчих проектів як складника емоційного відгуку; застосування системи навчальних i творчих завдань, інтерактивних методів і прийомів, активних форм організації практичної діяльності студентів на заняттях з образотворчого мистецтва; посилення емоційного аспекту у викладанні дисциплін образотворчого мистецтва.

Ключові слова: педагогічні умови, майбутній вчитель початкової школи, емпатія, проект, проектування, інтерактивні методи.

Стас Т. В. Педагогические условия формирования эмоциональной культуры будущих учителей начальной школы средствами изобразительного искусства.

В статье определены педагогические условия формирования эмоциональной 
культуры будущих учителей начальной школы средствами изобразительного искусства: обеспечение эмоционально-волевой регуляции содержания учебной деятельности; применения творческих проектов как составляющей эмоционального отклика; применение системы учебных и творческих задач, интерактивных методов и приемов, активных форм организации практической деятельности студентов на занятиях по изобразительному искусству; усиления эмоционального аспекта в преподавании дисциплин изобразительного искусства.

Ключевые слова: педагогические условия, будущий учитель начальной школы, эмпатия, проект, проектирование, интерактивные методы.

Stas T. V. Pedagogical conditions for forming emotional culture of future primary school teachers through fine arts.

The article outlines the pedagogical conditions for forming emotional culture of future primary school teachers through fine arts: providing emotional and volitional regulation of learning activity; applying creative projects as a part of emotional feedback; performing educational and creative tasks, interactive methods and techniques, active forms of practice at fine arts classes; enhancing emotional aspects of teaching fine arts.

Key words: pedagogical conditions, future primaty school teacher, empathy, project projecting, interactive methods.

Нині в педагогічній літературі накопичено певний досвід і окреслено різні підходи до визначення умов упровадження педагогічних технологій в систему шкільної освіти, що, на наш погляд, зумовлено наявністю різноманітних трактувань поняття «умова».

Поряд із визначеннями умови, як обставин, які забезпечують нормальну роботу чого-небудь; чинника, тобто рушійної сили, причини будь-якого процесу; сукупності особливостей засобів діяльності, спрямованої на досягнення якоїсь мети, забезпечення необхідного середовища, що зумовлює інтенсивність цієї діяльності; ми схильні до трактування цього поняття С. Висоцьким, який визначає умову як сукупність об'єктивних можливостей змісту навчання, методів, організаційних засобів його здійснення, коли забезпечується успішне розв'язання поставленого педагогічного завдання [2, с.91]. На нашу думку, таке визначення сутності окресленого поняття доцільно вважати прийнятним і щодо навчально-виховного процесу.

3 огляду на специфіку нашого дослідження під педагогічними умовами формування емоційної культури ми розуміємо сукупність об'єктивних можливостей змісту навчання, методів та організаційних засобів їх здійснення, що забезпечують успішне розв'язання завдань формування емоційної культури студентів.

Аналіз психолого-педагогічної літератури 3 теми дослідження, а також узагальнення даних, отриманих під час проведення констатувального етапу експерименту, дозволили виявити сукупність педагогічних умов формування емоційної культури майбутніх учителів початкової школи засобами образотворчого мистецтва.

Mema cmammi - розкрити педагогічні умови формування емоційної культури майбутніх учителів початкової школи засобами образотворчого мистецтва (формування емоційної культури майбутніх вчителів початкової школи засобами образотворчого мистецтва: забезпечення емоційно-вольової регуляції змісту навчальної діяльності; застосування творчих проектів як складової емоційного відгуку; застосування системи навчальних і творчих завдань, інтерактивних методів і 
прийомів, активних форм організації практичної діяльності студентів на заняттях 3 образотворчого мистецтва; посилення емоційного аспекту у викладанні дисциплін образотворчого мистецтва), враховуючи при цьому, що кожна умова має свої можливості і не може відокремлено повністю забезпечити успішність здійснення навчально-виховного процесу.

Однією 3 важливих умов формування емоційної культури майбутніх учителів початкової школи засобами образотворчого мистецтва $\epsilon$ забезпечення емоційновольової регуляції змісту навчальної діяльності.

Слово «емпатія» походить від грецького «раtho», що означає глибоке, сильне, чутливе почуття (відчуття), близьке до страждання. Префікс «ет» означає спрямований (скерований) всередину. Емпатію вивчали такі дослідники, як: К. Роджерс, К. Рудестам, С. Мелибруда, Г. Андреєва, Г. Перепечина та ін. Вони одностайні в тому, що емпатія виявляється насамперед у спілкуванні. Єдиного визначення даного поняття в наукових розвідках немає. Г. Перепечина підкреслює, що найчастіше повторюються чотири дефініції емпатії: розуміння почуттів, потреб інших; глибоко чутливе сприйняття події, природи, мистецтва; афективний зв’язок 3 іншими; відчуття стану іншої особи чи групи.

Емпатія пов'язана з проникненням у переживання іншого суб'єкта шляхом «відчування». Основними формами емпатії вважають співпереживання та співчуття. Співпереживання передбачає переживання суб'єктом тих же почуттів, які відчуває інший шляхом ототожнення 3 ним.

Почуття, співчуття та переживання допомагають адекватному розумінню інших людей. Уміння сприйняти почуття іншої людини як власні, здатність до емоційного відгуку $\epsilon$ необхідним компонентом спілкування, специфічним засобом пізнання людини людиною. Емпатія сприяє збалансованості міжособистісних стосунків. Розвинена емпатія - це ключовий фактор успіху в багатьох видах діяльності.

Відомо, що на формування емоційної культури особистості негативно відображається «психологічний клімат», що будується в колективі на несправедливих звинуваченнях, бездушші, зневажливому ставленні, ігноруванні інтересів, приниженні почуття людської гідності. Негативний психологічний клімат, що панував на перших етапах розвитку колонії часто призводив до конфліктних ситуацій, викликав i закріплював негативні емоції.

Розвиток і вдосконалювання викладачем педагогічного ВНЗ своєї емоційної культури припускає переосмислення власного педагогічного досвіду, аналіз емоційних виявів і поведінкових реакцій, причин, їх що зумовлюють, а також розвиток рефлексивних і емпатійних здібностей, подолання власної «педагогічності», відхід від стійких стереотипів педагогічної діяльності і спілкування й перехід на прогресивний варіант професійної самореалізації.

До числа умов формування емоційної культури майбутніх учителів початкової школи засобами образотворчого мистецтва необхідно віднести задоволення потреби у спілкуванні, розширенні сфери емоційних вражень. Проблема виховного впливу на емоції і почуття учнів, зазначає М. Якобсон, має два аспекти. По-перше, це питання про шляхи і прийоми впливу, які повинні зумовити досягнення певного рівня вихованості емоційної сфери людини, що росте. Це головне завдання, яке стоїть перед вчителем. По-друге, це питання про шляхи i прийоми впливів, які викликані необхідністю перевиховання деяких боків емоційної сфери учня. Це припускає процес більш серйозної перебудови почуттів і прагнень учня, зміни сутності його емоційного ставлення до оточуючого. Для правильного впливу на почуття дитини необхідні такі вміння: 
- уміння аналізувати емоційне життя учня на підставі цілісної картини його поведінки й окремих проявів. Такий аналіз допоможе педагогу 3 достатньою обгрунтованістю виявити причини, що призвели в тому чи іншому випадку до несприятливих зрушень в емоційному житті учня;

- уміння віднаходити правильні шляхи для необхідного впливу на учнів;

- уміння у процесі спілкування з учнями за необхідності «переключати» їх на інші емоційні стани і прагнення, уміння так змінити ситуацію, створити такі психологічні умови, що з часом вдається перебудувати емоційне ставлення учня до істотних явищ [7].

Досліджуючи особливості саморегулюючого компонента, ми вважаємо за доцільне розглянути такі поняття як «емоційний стрес», «емоційна напруга», «емоційна усталеність», оскільки педагогічна діяльність $є$ емоційно напруженою.

На думку більшості сучасних дослідників емоцій, емоції «негативного знаку», які виникають у важких $\mathrm{i}$ критичних ситуаціях (у ситуаціях підвищеної відповідальності за успішний результат діяльності, яку виконує людина - дії в умовах ризику, в ситуації екзамену і при травмуючому психічному впливі - втрата близької людини, образа, приниження власної гідності тощо) обумовлюють специфічний психічний стан, який отримав назву емоційного чи психологічного стресу.

Другою умовою формування емоційної культури майбутніх учителів початкової школи засобами образотворчого мистецтва $\epsilon$ застосування творчих проектів як складової емоційного відгуку.

Емоційні переживання ми розглядаємо як цінність, необхідну для повноцінного розвитку особистості, появу емоційного відгуку - як цілісну та комплексну реакцію. Необхідними компонентами емоційної культури $є$ пізнавальна активність, зростання духовних потреб, широта інтересів, вияву гуманістичних начал у поведінці, потреба у творчій діяльності. На наш погляд, творче проектування сприяє формуванню емоційної культури майбутніх учителів початкової школи. Розглянемо особливості творчого проектування.

Проектування (від лат. Projectus - кинутий вперед) - тісно пов'язане 3 наукою та інженерією, це діяльність із створення проекту [4]. Водночас проектування принципово відмінне і від науки, і від інженерії. Перш за все, вони відрізняються формально, за продуктом. Продукт наукового дослідження - знання. Продукт проектування - проект.

Проект - система понять, яка дає абстрактне уявлення виробу. Сукупність властивостей і особливостей матеріального комплексу, отримана у результаті синтезу, що характеризує творчий або виконавчий задум [6, с. 20].

Як і будь-яка діяльність, проектна діяльність має певну структуру. Важливим питанням у плані нашого дослідження є виявлення особливостей елементів структури проектної діяльності.

Необхідно зазначити, що цей метод має багато переваг. У межах окресленої проблеми, звертаємо увагу на наступні:

- впровадження методу в навчально-виховний процес забезпечує можливість міждисциплінарної інтеграції:

- використання методу на уроках обслуговуючої праці сприяє поєднанню індивідуальної і колективної діяльності учнів, що дозволяє реалізовувати на практиці педагогіку співробітництва і сприяє самореалізації особистості.

- організація проектної діяльності забезпечує реалізацію вікових потреб особистості у самостійній і практичній діяльності та забезпечує можливість бачити 
результати своєї діяльності через набуття нових знань та життєвого досвіду [1].

Методика проектування - це не формула і навіть не інструкція, а послідовність подій, що складають процес проектування, у рамках якого можливий логічний розвиток конструкції [5, с. 58].

Аналіз представленої вище літератури дозволяє нам виокремити такі основні етапи проектної діяльності студентів: дослідницький (підготовчий) етап; конструкторський етап; технологічний етап; завершальний етап.

Зазначимо, що робота над проектом, як будь-яка творчість вимагає певного ступеня свободи. Тому автор проекту має право змінювати послідовність викладу матеріалу, не вносити окремі розділи з рекомендованого переліку або доповнювати те, що може покращити якість роботи [3].

Підкреслимо, що структура побудови проекту у багатьох випадках залежить від його типу, специфіки навчального предмету, авторських педагогічних розробок конкретної теми проекту, тому і може бути різна кількість етапів.

Проектна діяльність майбутніх учителів початкової школи - це динамічний неперервний цілеспрямований процес активності, спрямований на розв'язання завдань з розробки ідеї, їі реалізації та отримання результату проектної діяльності, що зумовлює зміни об'єктивного та суб'єктивного характеру розвитку сутнісних сил особистості студентів.

Проектна діяльність має низку позитивних сторін: дозволяє студентам самостійно або в групі виявити себе, максимально випробовуючи свої можливості; спробувати свої сили, використати свої знання, принести користь і показати публічно досягнутий результат. Вона спрямована на розв'язання цікавої для них проблеми, що сприяє розвитку самостійності у формуванні студентами мети майбутньої діяльності і має практичний характер. Метод творчих проектів, як спосіб навчання студентів проектній діяльності- комплексне методичне утворення, що синтезує в собі як традиційні, так і нетрадиційні прийоми навчання. На різних етапах учитель може здійснювати добір тих методів і прийомів роботи, які є необхідними на даний момент, і які збагачують навчальний процес.

Наступною педагогічною умовою є застосування системи навчальних і творчих завдань, інтерактивних методів і прийомів, активних форм організації практичної діяльності студентів на заняттях з образотворчого мистецтва.

Завдяки сучасній техніці й інформаційно-комунікативним технологіям навчання надана можливість поглиблення та засвоєння знань, що надає нового потужного імпульсу для розвитку самостійної пізнавальної активності.

Застосування нових інформаційних технологій у традиційному навчанні дозволяє диференціювати процес навчання 3 урахуванням індивідуальних особливостей студентів, дає можливість творчо працюючому викладачеві розширити спектр способів викладу навчальної інформації, дозволяє здійснювати гнучке керування навчальним процесом, є соціально значимим і актуальним.

Особливо цікаво можна використати мультимедіа-технології для ілюстрації розповіді вчителя на етапі пояснення нового матеріалу. Комп'ютерні програми допомагають створити різноманітні зорові ілюстрації й звуковий супровід, що сприяє кращій реалізації принципу наочності в навчанні.

Слайди, виведені на великий екран становлять наочний матеріал, що застосовується задля пожвавлення лекції. Цей матеріал може бути різним (звичайна ілюстрація); використання анімації в слайдах; мультимедіа -панорама (більше цікавий прийом наочності).

Застосування рольових ігор як метод актуалізації емпатійних властивостей 
особистості в моделюється педагогічної діяльності повинно відповідати таким вимогам: невизначеність умов гри, що надає суб'єкту велику варіативність дій; включення суб'єкта в конфліктну ситуацію, «провокують» співпереживання і допомагає поведінку; вибір і виконання реальних завершених дій; створення можливості уточнення відомостей, введення додаткових змінних ситуацій; виконання експериментатором ролі режисера.

Педагогічна суть ділової гри - активізувати мислення студентів, підвищити самостійність майбутнього фахівця, внести дух творчості в навчанні, наблизити його, підготувати до професійної практичної діяльності. Головним питанням у проблемному навчанні виступає «чому», а в діловій грі «що було б, якби...».

Аналізований метод розкриває особистісний потенціал студента: кожен учасник може продіагностувати свої можливості поодинці, а також й у спільній діяльності 3 іншими учасниками. У процесі підготовки й проведення ділової гри, кожен учасник повинен мати можливість для самоствердження й саморозвитку. Викладач повинен допомогти студентові стати в грі тим, ким він хоче бути, показати йому самому його кращі якості, які могли б розкритися в ході спілкування. Ділова гра- це контрольована система, тому що процедура гри готуватися, i коректується викладачем. Якщо гра проходить у планованому режимі, викладач може не втручатися в ігрові відносини, а тільки спостерігати й оцінювати ігрову діяльність студентів. Але якщо дії виходять за межі плану, зривають мети заняття, викладач може відкоригувати спрямованість гри і її емоційний настрой.

Імітаційні вправи ближче до навчальних ігор. Їх ціль- надати студентам можливість у творчій обстановці закріпити ті або інші навички, акцентувати увагу на якому-небудь важливому понятті, категорії, законі. В умові має втримуватися обов'язкове протиріччя, тобто в імітаційній вправі $є$ елемент проблемності.

Четвертою педагогічною умовою формування емоційної культури майбутніх учителів початкової школи засобами образотворчого мистецтва $\epsilon$ посилення емоційного аспекту у викладанні дисциплін образотворчого мистецтва.

Особливості підготовки майбутнього вчителя початкових класів щодо використання образотворчого мистецтва полягають у підготовці студентів за трьома напрямами. Перший, базисний напрям, грунтується на формуванні у студентів естетичного сприймання творів декоративно-прикладного мистецтва на основі розуміння його символічно-знакової мови. Другий, методичний, - на усвідомленні педагогічного потенціалу образотворчого мистецтва, що передбачає конкретизацію педагогічних умов використання мистецького компонента у змісті професійної підготовки майбутніх учителів початкових класів. Третій, практичний - практичне виконання творів образотворчого мистецтва.

Для того, щоб мистецтво увійшло до шкільного життя, необхідно приділяти достатньо уваги образотворчому мистецтву в процесі професійної підготовки учителів, i, зокрема, педагогів, які викладають у початковій школі. Перш за все, варто поглибити знання майбутніх учителів про образотворче мистецтво, акцентуючи увагу на малюнку, композиції, кольорі, линії, народних орнаментів тощо. Безумовно, вони мають бути готовими до використання образотворчого мистецтва у навчальновиховному процесі, по-перше, володіти методикою і практичними навичками; подруге, - володіти художніми та конструктивними вміннями.

Знання визначається як особлива форма духовного засвоєння результатів пізнання, процесу відображення дійсності. Суб'єкт повинен застосовувати знання у практичній діяльності.

Важко переоцінити ту роль, яку відіграє викладання мистецьких дисциплін для 
розвитку особистості кожного учня. Поєднання двох напрямів використання мистецтва в школі- виховання через мистецтво (мистецтво як викладання загальноосвітніх предметів) i виховання у мистецтві (викладання мистецьких дисциплін) - створюють емоційну атмосферу привабливості, шкільного життя учнів і вчителів.

Отже, у професійному становленні фахівця i, зокрема, майбутніх учителів початкової школи суттєвим є формування особистої позиції: установки, ставлення до професійної художньо-педагогічної діяльності, образотворчого мистецтва.

\section{Література}

1. Архангельский С. И. Лекции по теории обучения в высшей школе / С. И. Архангельский. - М. : Высшая школа, 1974. - 278 с. 2. Белкин А. С. Ситуация успеха. Как ее создать: [кн. для учителя] / А. С. Белкин. - М. : Просвещение, 1991. 176 с. 3. Бодалев А. А. Психологические условия гуманизации педагогического общения / А. А. Бодалев // Сов. педагогика. - 1990. - № 12. - С. 65-71. 4. Дидактика современной школы: [пособие для учителей] / Б. С. Кобзарь, Г. Ф. Кумарина, Ю. А. Кусый и др.; под ред. В. А. Онищука. - К. : Рад. шк., 1987. - 351 с. 5. Кэррол Э. Изард. Психология эмоций / Кэррол Э. Изард. - Санкт-Петербург, 2000. 6. Лафренье Питер. Эмоциональное развитие детей и подростков/ Лафренье Питер. - СПб. : прайм - ЕВРОЗНАК, 2004. - 256 с. 7. Платонов К. К. Краткий словарь системы психологических понятий / К. К. Платонов. - М. : Высшая школа, 1984. $-412 \mathrm{c}$.

УДК 378

Лілія Сушенцева

\section{ВПЛИВ ГЛОБАЛІЗАЦІЙНИХ ПРОЦЕСІВ У СУСПІЛЬСТВІ НА ЗМІСТ ПІДГОТОВКИ ПРОФЕСІЙНО МОБІЛЬНОГО КВАЛІФІКОВАНОГО РОБІТНИКА}

Сушенцева Л. Л. Вплив глобалізаційних процесів у суспільстві на зміст підготовки професійно мобільного кваліфікованого робітника.

У статті розглянуто актуальні питання впливу глобалізаційних процесів у суспільстві на відбір і структурування змісту підготовки майбутніх професійно мобільних кваліфікованих робітників. Розкрито сутність глобалізації та іiі політичні, економічні, культурні й соціальні аспекти. Обгрунтовано зростання інтересу до проблеми формування професійної мобільності майбутніх кваліфікованих робітників в умовах глобалізаційних змін у суспільстві та появі ринку праці.

Ключові слова: глобалізація, професійна мобільність, ринок праці, зміст професійної підготовки, кваліфіковані робітники.

Сушенцева Л. Л. Влияние процессов глобализации в обществе на содержание подготовки профессионально мобильного квалифицированного рабочего.

В статье рассмотрены актуальные вопросы влияния глобализационных процессов в обществе на отбор и структуризацию содержания подготовки будущих профессионально мобильных квалифицированных рабочих. Раскрыта сущность глобализации и ее политические, экономические, культурные и социальные аспекты. Обоснованно рост интереса к проблеме формирования профессиональной мобильности будущих квалифицированных рабочих в условиях глобализационных изменений в обществе и появления рынка труда.

Ключевые слова: глобализация, профессиональная мобильность, рынок труда, 